\title{
Vám- és adószedők a magyar pénzügyi igazgatásban az államalapítástól a kiegyezésig
}

A pénzügyi igazgatás egyidős az állammal, hiszen az állam születésének pillanatától beszélhetünk államháztartásról, állami bevételekről, melyek fedezik az állami feladatok ellátásával járó kiadásokat. Az állam, illetve az államháztartás müködésének biztosításához szorosan kapcsolódik az a személyi állomány, amely speciális ismeretei, szakértelme alapján ellátta/ellátja az állami feladatokat, lehetővé teszi a hatalomgyakorlást.

A középkori államháztartás egyik jellemző sajátossága volt, hogy a király magánbevételei és a kormányzat jövedelme mintegy összeolvadtak. A középkori közfelfogás nem a mai értelemben tett különbséget a király magánjogi jogviszonyon alapuló földesúri és közjogi jogviszonyon alapuló államgazdasági bevételei és kiadásai között.

HÓMAN Bálint ${ }^{1}$ az államháztartás bevételeit - megfelelően a fejlődési fokozatoknak — három csoportba sorolta. Megkülönböztetett magángazdasági (domaniális) jövedelmeket, királyi felségjog alapján beszedett, úgynevezett regálejövedelmeket, továbbá önként megajánlott, a szó eredeti középkori értelmében vett adókat. ${ }^{2}$

Az államháztartás eleinte a király magángazdasági jövedelmein, a földbirtokain ${ }^{3}$ nyugodott, melyet az uralkodó magánjogi jogviszony alapján vett igénybe. A patrimoniális államban ugyanis a királyi hatalom alapja a birtokolt magángazdaság és földbirtokmennyiség volt, az uralkodó ezáltal rendelkezett elegendő, mások fölött hatalmat biztosító fegyveres kézzel és gazdasági erővel. ${ }^{4}$

Ebben az időszakban a magyar királyok fő bevétele a terményszolgáltatásból, illetve a robotmunkából származott. A hadügyi és közigazgatási funkciókat a királyi földbirtokon élők látták el, így a fejlődés ezen első korszakában elsősorban a magánháztartási és udvari kiadások, továbbá a kormányzati és külügyi, diplomáciai kiadások terhelték a kincstárat.

Már a domaniális államháztartás időszakában megjelent néhány, a királyi felségjogban gyökerező királyi haszonvétel, vagy más néven regálejövedelem (pl.: kezdetleges fejadók, vásárpénz, közlekedési vámok). Ez alatt olyan jogosítványokat értünk, melyekkel a király az alattvalói gazdasági erejét királyi felségjoga, azaz közjogi jogviszony alapján veszi igénybe. Ezeknek a többnyire illetéktermészetủ szolgáltatásoknak kezdetben nem volt jelentős szerepük, teljesítésükért az alattvalók valamiféle ellenszolgáltatásban részesültek (pl.: védelem, jogbiztonság, vásári elárusítóhely biztosítása).

A patrimoniális hatalom bomlásával a felségjogok pénzügyi regalitássá, tulajdonképpen ellenszolgáltatás nélküli regálejövedelmekké alakultak és a XII. század végén már a domíniumokkal egyenrangú helyet foglaltak el a bevételi források között. Ebben az időszakban a hadügyi és közigazgatási feladatok ellátása az alattvalókra, leginkább a nagybirtokosokra hárult. Mint a közigazgatás fótisztviselői jelentek meg, s velük magánjogi (familiáris) viszonyban álló tisztviselőket alkalmaztak. $\mathrm{Az}$ uralkodó díjazásban részesítette őket, mely eleinte természetben vagy birtokadományozással történt, de a regálegazdaság későbbi időszakában már a készpénzben való fizetés is megjelent.

A XIII. század elején megkezdődött a várbirtokok rendszeres eladományozása, mely által a föld, a patrimoniális királyi hatalom alapja kicsúszott az uralkodók kezéből. Ezzel párhuzamosan a regálejövedelmek adományozása is megindult, így a regálejövedelem lassanként magángazdasági szolgáltatássá vált, $\mathrm{s}$ ez végső csapást jelentett az államháztartás számára, hiszen a legjövedelmezőbb bevételi forrásaitól esett el a király.

Az állam szükségleteit tehát már nem fedezték megfelelően a domaniális- és a regálejövedelmek (együtt: rendes jövedelmek), ezek pótlását, kiegészítését biztosítani kellett. Ekkor jelentek meg az úgynevezett rendkívüli jövedelmek, az adók, segélyek (gyüjtőnéven a források collecta vagy exactio néven említik), melyek igénybevételére - a rendiség megjelenésével - kizárólag a rendek előzetes hozzájárulásával volt lehetőség, akik ezen rendkívüli jövedelmek megszavazását mindig önkéntesen tették. ${ }^{5}$

\section{Az Árpád-házi uralkodók intézkedéseinek hatásai a pénzügyigazgatás szervezetfejlődésére}

A domaniális államháztartás időszakában a pénzügyi igazgatás teljesen összefonódott a földbirtokok gazdasági igazgatásával, ennek megfelelően a pénzügyi igazgatás decentralizált volt. Vezető tisztségviselői az ispánok voltak, a vármegyékben a megyésispán, a királyi magánuradalomban a nádorispán vagy nádor. Feladatkörükbe tartozott elsősorban a magángazdasági terményszolgáltatás behajtása, továbbá a vármegyék ispánjai foglalkoztak a regálejövedelmek beszedésével is, melyért fizetésképpen a behajtott jövedelmek egyharmadában részesültek.

$\mathrm{Az}$ említett tevékenységek ellátása érdekében természetesen az ispánok mellett a várbirtokon a várnép, a királyi magángazdaságban az udvarnokok müködtek, akik közül a tárnokok voltak a terményjövedelmek beszedői, kezelői, a vámosok szedték a vám- és vásárpénzt, az adót a dénárszedők 
gyüjtötték be, a bitangjószág összegyüjtői a johszedők voltak, de a források utalnak még ebben a korban bányászokra, sóvágókra és sótisztekre is. A várnépek és az udvarnokok különféle kategóriái századokba és tizedekbe voltak beosztva, élükön a száznagyok és a tíznagyok álltak. ${ }^{6}$

Központosított igazgatásról ebben az időszakban nem igazán beszélhetünk, az egyetlen központi szervezet, ahová a királyi jövedelmek befolytak, a királyi kincstár volt, melynek élén szintén a nádor állt.

Fentieknek megfelelóen a pénzügyi igazgatás ebben az idöszakban a nádor kezében összpontosult, s szerepe - a központi ellenőrzés bevezetésének szükségessé válásával — még inkább erősödött, s ,,az ország első közjogi méltóságává emelkedett" 7 .

A nádor törvénykezési jogkörének bővülését követően — tekintettel a megnövekedett feladataira — már nem felelhetett meg eredeti hivatásának, így a pénzügyi igazgatási funkcióit fokozatosan más tisztviselőkre kellett ruháznia. A pénzügyi igazgatás vezetése, illetve a központi ellenőrzés funkciói (később a kincstár vezetése, a regálék igazgatása is) az időközben a tárnokok élére kinevezett új udvari fötisztre, a tárnokmesterre hárultak.

A nádor pénzügyi igazgatásban betöltött szerepe a további fejlődés szempontjából különös jelentőségünek bizonyult, hiszen az ő tevékenysége képezte alapját a tárnokmesteri hivatal kialakításának, valamint a későbbiekben az önálló központi pénzügyi szervezet létrehozásának.

Kiemelendő továbbá, hogy ezen időszakban - a központi igazgatás fokozatos térnyerésével - a megyés ispánok már csak támogató szerepkörben jelentek meg a pénzügyigazgatásban.

A pénzügyi igazgatás személyi állományának fejlödése szempontjából fontos továbbá az udvarnokosztály, illetve a várnépek egységének megbomlása, az azonos tevékenységi ágak kategóriáinak külön-külön főtisztek (mesterek, magisterek) irányítása alá helyezése, a foglalkozásszerü differenciálódás megjelenése. ${ }^{8}$

A XIII. században - köszönhetően a régi jövedelmek apadásának és újak keletkezésének, valamint az államháztartás súlypontjának a regálékra való helyeződésének - a régi pénzügyigazgatási szervezetrendszer átalakult, felváltotta a bérletrendszer, a regálék bérbeadása. A bérlők nem a király tisztviselői voltak, hanem a kincstárral szerződéses jogviszonyban álló üzletemberek, akik pénzügyi tisztviselőként a velük magánjogi jogviszonyba kerülő familiárisaikat alkalmazták. Tehát a bérletrendszer életbe lépésével csak a vezető funkcionáriusok, a bérlök függtek a királytól, az alkalmazottak a bérlő kizárólagos fennhatósága alá tartoztak. ${ }^{9}$

A magyar állam pénzügyigazgatásának újjászervezése az Árpád-ház férfi ága kihalását követően A közigazgatás az Árpád-ház férfi ágának kihalását követően teljesen szétzilálódott, a fötisztségeken a föurak marakodtak. Ebben a kilátástalannak tünő helyzetben került a trónra Károly Róbert, aki a pénzügyigazgatás újjászervezésében látta az államháztartás stabilizálásának lehetőségét. Az, hogy a pénzügyi igazgatást a régi, domaniális államháztartás időszakának megfelelő módon rendezzék nem lehetett célravezető, viszont a bürokratikus igazgatás felépítésének sem jött még el az ideje.

A bérletrendszerủ kezelésnek azonban megvoltak az előnyei, melyet az uralkodó fel is ismert, hiszen a bérlők üzleti alapon müködtek, a költségeket igyekeztek minimálisra redukálni, a kincstárnak azonban jóval nagyobb bevételt tudtak biztosítani, mint a királyi igazgatási szervezetek. Ez a jövedelem pedig teljes egészében a kincstárba folyt be, hiszen az ügykezelés költségei (később a központi ellenörzés költségei is) a bérlőt terhelték. ${ }^{\mathbf{1 0}}$

Ezen elönyök ismeretében Károly Róbert nem akarta a meglévő szervezetet teljesen új alapokra helyezni, hanem felismerve a bérletrendszer hibáit, azokat orvosolva kísérelte meg a pénzügyi igazgatást újjászervezni. Úgy ítélte meg, hogy a hibák kiküszöbölése tekintetében az a legfontosabb, hogy a bérlők személyének kiválasztása során megteremtse a személyi biztosítékokat, így kezdetben nemes urakat állított a regálejövedelmek kezelésének élére, azonban 1323. évi pénzügyi reformjának kudarca után belátta, hogy a pénzügyek vezetéséhez nem elég a születési előjog, a tisztesség és a megbízhatóság, hanem megfelelö szakértelem (üzleti hozzáértés) is szükséges. Felismerte azt is, hogy a személyi garanciák nem elegendőek minden gond megoldására. Arra törekedett, hogy — a központi pénzügyi igazgatási szervezet megszilárdítása mellett — kiépítse a külső szervezetrendszert, szabályozza a hatásköröket és a müködést, biztosítsa a megfelelő központi ellenőrzést és intézményesítse a büntetőjogi felelősségre vonást. ${ }^{11}$

A központi pénzügyi igazgatásban a vezető szerep ebben az időszakban is a tárnokmesteré volt. A tisztség betöltésénél Károly Róbert uralkodása kezdetén a politikai szempontok domináltak, nem a hozzáértés, a rátermettség volt a mérvadó, így ezek a fötisztviselők általában csak névleges vezetők voltak. Amikor a király hatalma kezdett megszilárdulni, a tárnokmesteri tisztséget is régi megbízható embereivel töltötte be. Ahogyan HóMAN Bálint írja „Károly Róbert ritka szerencsével, vagy inkább kitủnő emberis- 
merettel válogatta meg tanácsosait. Bizalmas hívei közül minden fötisztségre a legalkalmasabb embert szemelte ki." 12

A tárnokmester állt az államháztartás élén, irányította az ország pénzügyi és gazdaságpolitikáját, hozzá tartozott a külső pénzügyigazgatási szervek ellenőrzése és felügyelete, a regáléigazgatás személyi állományának ő volt a legfőbb közigazgatási és bírói hatósága, ő volt a kincstár vezetője, teljes juriszdikcióval rendelkezett a városok felett. Hatáskörének ilyen bővülése mellett már nem láthatta el egyedül ezeket a tevékenységeket, így szükség volt egy neki alárendelt képviselöre, aki eleinte a tárnoknagy, majd a kincstartó címet viselte és a későbbiek folyamán, mint kincstartó, ő vált a pénzügyek legfőbb vezetőjévé is. ${ }^{13}$ Természetesen alárendeltségébe tartoztak a tárnokok és kamarások is.

A központi pénzügyi igazgatás megszilárdítása mellett Károly Róbert nagy hangsúlyt fektetett a külső pénzügyi igazgatási szervezet kiépítésére, vagyis a kamarák megfelelő müködtetésének biztosítására. Az Árpád-korban is léteztek már kamaraispánságok, de azok nem voltak pontosan körülhatárolt, hatáskörileg is elkülönített szervezetek. Károly Róbert érdeme abban áll, hogy ezeket territoriális szervezetekké alakította, egy meghatározott terület pénzügyi hatóságává tette, ezáltal az ország kerületekre, kamaraispánságokra tagolódott. ${ }^{14}$

A kamarák élén a kamaraispán állt, aki a királlyal szerződéses jogviszonyban lévő bérlő volt és többnyire - a pénzüzlettel foglalkozó - városi polgárság köréből került ki. Közvetlen felelősséggel tartozott az uralkodónak. A kamarai személyzet a bérlő, vagyis a kamaraispán közvetlen hatósága alá tartozott, az ő magánalkalmazottai, familiárisai, serviensei, officiálisai voltak, akik felett teljes közigazgatási és bírói joghatósággal rendelkezett. Későbbiekben bővült a juriszdikció köre a financiális kihágásokban való teljes körü bíráskodás és bírságolás jogával.

A kamaráknak magánjogi jogviszonyon alapuló szervezete volt, mely lényegében azonosnak látszik a közigazgatás más ágaiban is megjelenő hübéri természetű szervezettel. HóMAN Bálint ${ }^{15}$ szerint azonban a kamarai familiaritás lényegesen eltér a közigazgatás más területén tapasztalt familiaritástól. Hogy mennyiben igaz ez, azt az alábbiak szerint foglalom össze:

A kamarai familiaritás egy ideiglenes jellegü kapcsolat volt, amely magánjogi viszonyt jelentett a kamaraispán, mint bérlő és a kamarai alkalmazott között, hiszen kizárólag a bérleti szerződés időtartamára (általában 1 év) szólt, szemben a közigazgatás egyéb területére jellemző familiaritással, mely állandó jellegü kapcsolatra épülő magánjogi jogviszony volt a birtokos és a familiáris között. A közfunkció ellátása a kamarai igazgatásban ebben az időszakban valamiféle állandó jelleget kezdett ölteni, hiszen gyakran tapasztalható, hogy a szakértelem okán az alkalmazott nem kizárólag egy kamaraispán mellett látta el feladatait, hanem akár több, egymást követő ispán irányítása alatt is dolgozhatott. A közigazgatás egyéb területén viszont a közfeladatok ideiglenes ellátása volt a jellemző. A familiáris alkalmazás arra az időszakra szólt, amely alatt a birtokos úr betöltötte a tisztségét. Amíg a közigazgatás egyéb területein a familiaritás feudális természetü jelenség volt, addig a pénzügyi igazgatásban a familiaritás inkább az újkori munkaadó és munkavállaló viszonyára emlékeztet.

\section{Mátyás király közigazgatási reformja}

A közigazgatás fejlődéstörténetében a XV. század szinte egész Európában fontos korszaknak tekinthető, mivel ezen időszak átmenetet alkotott a hagyományos személyes jellegü és az új hivatali jellegű közszolgálat között. Magyarországon Mátyás uralkodásának időszakára esett ezen változás. ${ }^{16}$ Megszilárdult az a hivatali szervezet, amely megfelelt a központosítás elvárásainak, ${ }^{17}$ és megvalósult a pénzügyi igazgatás átszervezése is.

A XV. században a legmagasabb rangú pénzügyi tisztviselő a királyi kincstartó volt, akinek jellemzően foúri származása révén - csekély köze volt a tényleges irányításhoz. Ez Mátyás uralkodásának idején kezdett változni, a kincstartó egyre nagyobb befolyással bírt a pénzügyek tényleges vezetésére, 1467-1472 között sorozatos pénzügyi reformokra került sor. A kincstartó állt pénzügyi föhivatal élén, az alkincstartó volt a helyettese, de dolgoztak a hivatalban titkárok, jegyzők, egy fizetőmester és számvevők is. A kincstartó felügyelte a sóbányák, sóhivatalok, a bánya- és pénzverőkamarák ispánjait, valamint a harmincadosokat, de ő nevezte ki és neki számoltak el az adóbeszedők is. ${ }^{18}$

A reformok megvalósítását követően a pénzügyi igazgatásban a kincstartó familiárisai vettek részt. Vagy állandó, vagy alkalmi jellegủ megbízások (ilyenek például az adószedők) alapján végezték feladataikat, pénzben és természetben kaptak fizetést, általában az általuk kezelt jövedelmekböl részesültek. Ahogyan az már Károly Róbert uralkodása idejében is gyakorlat volt, hogy a pénzügyi 
igazgatásban a familiaritás nem volt életre szóló, melyhez az alkalmazottak ipari és pénzüzleti tevékenysége ${ }^{19}$ és ennek hivatásszerü gyakorlása is hozzájárult. ${ }^{20} \mathrm{Az}$ alkalmazottaknak az eltávozás előtt számadást kellett készíteni, hiszen olyan feladatkörben dolgoztak, ahol jelentős bevételeket kezeltek.

A pénzügyi igazgatásban egyre jelentősebb szerepet kapott a tapasztalat, gyakorlat meglétének kérdése, melyet nem csak az uralkodó várt el a fötisztviselöktöl, hanem a kincstartó is olyan személyeket nevezett ki alsóbb pozíciókba, akik már dolgoztak a pénzügyi igazgatásban vagy más hivatalban. Egyre fontosabb lett a képzettség, a müveltség is. Ebben a korszakban már néhány egyetemi végzettséggel rendelkező személy is található volt a központi hivatalnokok között. A központi pénzügyi igazgatás vezetői és a sóhivatalok kamarásai között viszonylag nagy számban dolgoztak litteratus/deák müveltségüek, a harmincadosok és a pénzverőkamara-ispánok vonatkozásában azonban kevésbé gyakori az ilyen típusú műveltség. A litteratus műveltséggel bírók körében a legkülönbözöbb származású személyek fordultak elő, bárói rangú személyeket ritkán, középnemeseket is kevés számban választották ezt a pályát. A pénzügyi igazgatásban tevékenykedők többségét a kisnemesség alkotta, de megjelentek a pénzügyi igazgatásban a nem nemes és a nem polgár deákok is. Sok alacsony származású tehetséges fiatal elött nyílt meg ekkoriban a lehetőség hivatalnoki pályára kerülésre.

Hogy miért a pénzügyi igazgatás adott erre lehetőséget? Ennek okait elsősorban a pénzügyi adminisztráció jellegében kell keresnünk. A pénzügyek intézéséhez ugyanis megfelelően képzett személyzetre volt szükség, hiszen a költségvetés összeállítása, a számadások elkészitése komoly szakértelmet igényelt. Nem is szólva a harmincadosokról, a sóhivatalok alkalmazottairól, akinek a napi munkájukhoz szükség volt például a piaci árak ismeretére, vagy a bányakamarák tisztviselöiről, akiknél elengedhetetlen volt a bányászati technikák ismerete. Mindezen túlmenően a pénzügyi tisztviselőknek tisztában kellett lenniük a jogszabályokkal, az egyéni és rendi kiváltságokkal is.

Amint az előbbiek alapján látható, egy központi hivatalnokréteg kezdett kialakulni ebben az időszakban, mely tagjainak familiárisain keresztül folyamatosan biztosított volt a magas müveltségü, képzett alkalmazottak utánpótlása. ${ }^{21}$

\section{A királyi kamara szerepe a közigazgatási apparátus fejlődésében}

HABSBURG Ferdinánd trónra lépésekor ígéretet tett arra, hogy a magyar nemzet kiváltságait, jogait, régi alkotmányát és szokásait tiszteletben tartja, melyet a pénzügyi igazgatással kapcsolatban meg is tartott. Pénzügyi politikája a meglévő dolgok fenntartására, de intenzívebb kiaknázására irányult, amit a pénzügyi szervezet tökéletesítésével, müködésének fejlesztésével szeretett volna elérni. ${ }^{22}$

Ferdinánd igyekezett a vidéki szervezeteket, a kamarákat újjászervezni, de emellett létrehozott egy olyan központi hatóságot is, amely — bár magyar alapokra (kincstartóság) épült — mégis újnak mondható. Ez volt a Magyar Királyi Kamara, mely 1528-ban budai székhellyel jött létre, a török hadak beáramlásának hatására azonban a kamarát 1531-ben újjászervezték Pozsonyban. Később, az észak-keleti országrészekben a kellö adminisztráció, a jövedelmek könnyebb (valójában inkább tényleges) begyüjtése, továbbá ezen területek török hódoltságtól való védelme, valamint az Erdélyi Fejedelemség fennhatóságának ezen területre való kiterjesztésétől történő megóvása érdekében, Kassán létrehozták a Szepesi Kamarát, mely bizonyos hatásköri átfedések mellett, de jogilag a Magyar Kamara alárendelt szerveként müködött. ${ }^{23}$

A Magyar Kamara kollegiális szervezetként müködött, döntéseit testületi formában hozta meg, ezáltal legfontosabb szerve a tanács volt, mely elnökből és tanácsosokból állt. Az elnöki tisztséget rendszerint föpapok töltötték be, a tanácsosok pedig főnemesek (néha föpapok), illetve birtokos nemesek voltak. Az ügyintézésben a titkárok (később az altitkárok is) föszerepet játszottak, intézték a hivatali levelezést, jegyzőkönyvet vezettek a tanácsüléseken, de ők készítették el a kamarai utasítások, szabályzatok tervezeteit is. A Magyar Kamarában a tanács mellett több segédhivatal is müködött, így az iroda (fogalmazók és írnokok végeztek tisztázási, másolási feladatokat), az irattár (a lajstromozók gondozták az iratokat), a pénztár (pénztáros és később a segédje is a pénzkezeléssel kapcsolatos tevékenységeket végezték) és a számvevőhivatal (számadásmester állt az élén, segédekkel és írnokokkal dolgozott, végezte az ellenőrzéseket, később helyetteseként megjelent az alszámadásmester). A későbbiek során a kamara több változáson is átesett, hatásköre is bővült, szervezete is átalakult, így a későbbi években már a kiadóhivatal és az iktatóhivatal is megjelent a szervezeti egységek között. ${ }^{24}$

A Magyar Kamarában a XVIII. században jelentős reformokat hajtottak végre az ügyintézés terén is. Annyira megsokszorozódtak a kamarai feladatok, hogy az egész ügyintézési munkafolyamatot meg kellett változtatni. Az első lépésben az ügyeket négy ügycsoportba (departamentum) osztották, sóügyi, 
harmincadügyi, fiscalitásokkal foglalkozó és gazdasági ügycsoportokba, melyekhez előadótanácsosokat neveztek ki. Később a fontosabb ügyeket az egyes departamentumok referenseiből álló bizottságok tárgyalták meg, de hamarosan az ügyek elökészítése is e bizottságok hatáskörébe került, így létrejöttek az önálló szervezettel és ügyvitellel rendelkező (sóügyi, gazdasági, jogügyi, városi, salétrom- és lőporügyi, harmincadügyi) bizottságok.

A Magyar Kamara ügyintézése fejlődésének következő jelentős állomását az ügyosztályi rendszer kialakítása jelentette, mely az ügyintézés valamennyi fázisára kiterjedt és lehetővé tette a kamara ügykörének annyi ügycsoportba való rendezését, amennyire valóban szükség volt. Ezek után több mint 20 ügyosztály kezdte meg müködését.

Az ügycsoportok ügyeinek intézésére rendelt személyi állomány (tanácsos, titkár, fogalmazó) együttmüködéséből II. József korában kialakult a büró, amely a tanácsost és személyzetét, s a személyzet munkahelyét, irodáját jelentette. ${ }^{25}$

A XVIII. században az ügyintézés fejlődésének hatására, a munka olyan szervezése vált szükségessé, amelyben biztosított volt a hozzáértés, a szakértelem. A rendi közigazgatást Európában, így Magyarországon is felváltotta a hivatásos közszolgálattá fejlődés korszaka. Az európai haladás állandó állami illetményrendszer bevezetése, a kiválasztás módjának és a tisztviselők kötelességeinek szabályozása - hatást gyakorolt a magyar pénzügyi- és a teljes közigazgatásra is, melyre tekintettel a hivatali szervezet müködése állandóvá vált, az igazgatási eljárás, az ügyintézés egységessé tétele megtörtént, a tisztviselői állás élethivatássá alakult. ${ }^{26}$

A kiválasztás alapfeltétele a szakképzettség és a gyakorlat lett. Mária Terézia a szakképzettség előmozdítása érdekében a nagyszombati egyetemet Budára helyezte, a tantárgyakat is megújította, Ratio Educationis reformjával pedig öt akadémiát létesített, melyek állami szolgálatra felkészítő képzést nyújtottak.

A hivatalokba ugyanakkor továbbra is a nemesség tagjai kerültek be, bár II. József idejében a nem nemesek is tölthettek be közfunkciót.

A közszolgálat rendszeresítése indokolttá tette mind az előlépés lehetőségének biztosítását, mind a minősítési rendszer bevezetését, mely II. József érdeme, aki a katonai minősítési rendszert ültette át a közigazgatásba.

A tisztviselő ettől az időszaktól kezdődően nyugdíjban is részesült, mely Mária Terézia idejében vált rendszeressé. ${ }^{27}$

Erre a korra jellemző az is, hogy egyes speciális pénzügyi igazgatási területeken (pl.: harmincadigazgatás) a hivatalviselésnek különleges feltételei is megjelennek, így a fegyverviselés, illetve a kaució $^{28}$ letételének kötelezettsége.

II. József halála után a bürokratikus rendszer további fejlődése megtorpant, utódai kénytelenek voltak engedményeket tenni a rendi igazgatásnak. Ez a megtorpanás azonban csak rövid ideig tartott. Mivel a közigazgatási feladatok száma nem csökkent, a közszolgálat pedig biztos álláslehetőséget, fix fizetést és nyugdíjat jelentett a nemesség számára, ezért a rendek nem tiltakoztak a fejlesztések ellen.

\section{Polgári közigazgatás megalapozása}

A magyar közigazgatás fejlődésében lényeges mérföldkő volt az 1848. évi polgári átalakulás, mely megteremtette a nemzeti önállóság kiépítésének lehetőségét, a dikaszteriális szervek helyett létrejött a parlamentnek felelös kormány (akkori kifejezéssel élve minisztérium), a közigazgatás vezetése az uralkodó helyett a kormány kezébe került. Az alkotmányjogi ismeretekkel ellentétben azonban a pénzügyi igazgatás terén nem voltak megfelelően felkészülve a polgári átalakulásra és a szabadságharc idején a közigazgatás rendezése is elmaradt.

Amíg 1848-1849-ben a pénzügyi igazgatás jelentős változásokon nem esett át (a hadban álló országban rövid két év alatt nem sikerült kiépíteni egy új adórendszert), addig a neoabszolutizmus rendszeréhez a pénzügy- és föleg az adóigazgatás terén néhány jelentős újítás füződik. Létrehozták a pénzügyi igazgatás új szervezetét, megalkották az anyagi adójogi szabályokat, lerakták a polgári pénzügy és adóigazgatás alapjait. Az egyenes adók kezelésére egy-egy országos pénzügyigazgatóságot szerveztek, melyek alatt Magyarországon 43 vármegyei adófelügyelőség és 244 járási adóhivatal múködött. Bélyeghivatalok, fogyasztási adóhivatalok, dohányraktárak is kialakításra kerültek, a karhatalmat pedig a pénzügyőrség szolgáltatta. ${ }^{29} \mathrm{~A}$ dualizmus időszakában kiépült a pénzügyigazgatóságok rendszere. Fokozatosan - a hetvenes évektől kezdődően — vármegyénként hoztak létre pénzügyigazgatóságot, amely a magyar pénzügyigazgatás középszintü komplex irányító szervezete volt. A magyar pénzügyigazgatóságok alárendeltségébe tartozott a vármegyében müködő valamennyi pénzügyi szakhatóság. A dualizmus időszakában 19 pénzügyi szakhatóság müködött ugyan a Magyar Királyságban, azonban nem volt jelen minden pénzügyi szakhatóság minden vármegyében ${ }^{\mathbf{3 0}}$ (I.sz. melléklet)

A közigazgatás megújítása azonban - a nagy apparátus miatt - költséges volt. A rendi igazgatással összevetve, ahol mintegy 7600 tisztviselő dolgozott, jórészt nyugdíjra való igény nélkül, a Bachrendszer közigazgatásában közel 18000 hivatalnokot alkalmaztak, akik rendszeres fizetést kaptak és nyugdíjra is jogosultak voltak. ${ }^{31}$

Kétségtelen, hogy a BACH-rendszer igazgatási formái sokkal szakszerübbek voltak a régi magyar közigazgatási formáknál. Az is igaz viszont, hogy a neoabszolutizmus közigazgatását idegennek, sokszor ellenségesnek érezték a kortársak, mivel az 1848-1849-es forradalom és szabadságharcot a cári 
birodalom fegyveres erejének a segítségével leverő idegen, a magyar nemzetet — a „Verwirkungstheorie" (jogeljátszás elmélet) hazug elmélete alapján - elnyomó hatalmi apparátushoz tartozott. ${ }^{32} \mathrm{~A}$ kiegyezést követően az új magyar független kormány a neoabszolutista rendszer azon szervezeteit, amelyek a közrend és közbiztonság fenntartása mellett a magyar nemzet elnyomását is kivitelezték (birodalmi csendőrség és birodalmi rendőrség) nem vette át. ${ }^{33}$ A pénzügyi szakhatóságokat és azok személyzetének jelentős részét azonban a felelős magyar kormány befogadta a polgári magyar állam szakhatóságai személyi állományának a körébe.

A közigazgatásban való részvétel egyfajta szolgálat, mely a magyarok életében elöször a király szolgálatát, később az egész állam szolgálatát jelentette. A közszolgálat sokáig csak a hatalmat és az azzal járó tiszteletet biztosította a hivatalt betöltők számára, hiszen nem járt fizetéssel, a hivatalnokok megélhetésüket saját birtokaik révén biztosították, e emellett látták el közfeladataikat. Később azonban az alkalmazás — átlépve feudális jellegén — állandóvá, sokak számára élethivatássá vált, mely megteremtette annak a lehetőségét, hogy a közigazgatásba kerülés előfeltétele legyen a szakképzettség, a megfelelő gyakorlat megléte, melyért cserébe rendszeres fizetést és nyugdíjat biztosított az állam.

MAGYARY Zoltán szavaival élve „legjobban kiépített és kidolgozott közigazgatásunk a pénzügyi”, ${ }^{34}$ mely az államlapítás óta sikeresen adaptálta a külföldi tapasztalatokat egyben megőrizve és továbbfejlesztve a nemzeti szakmai hagyományainkat.

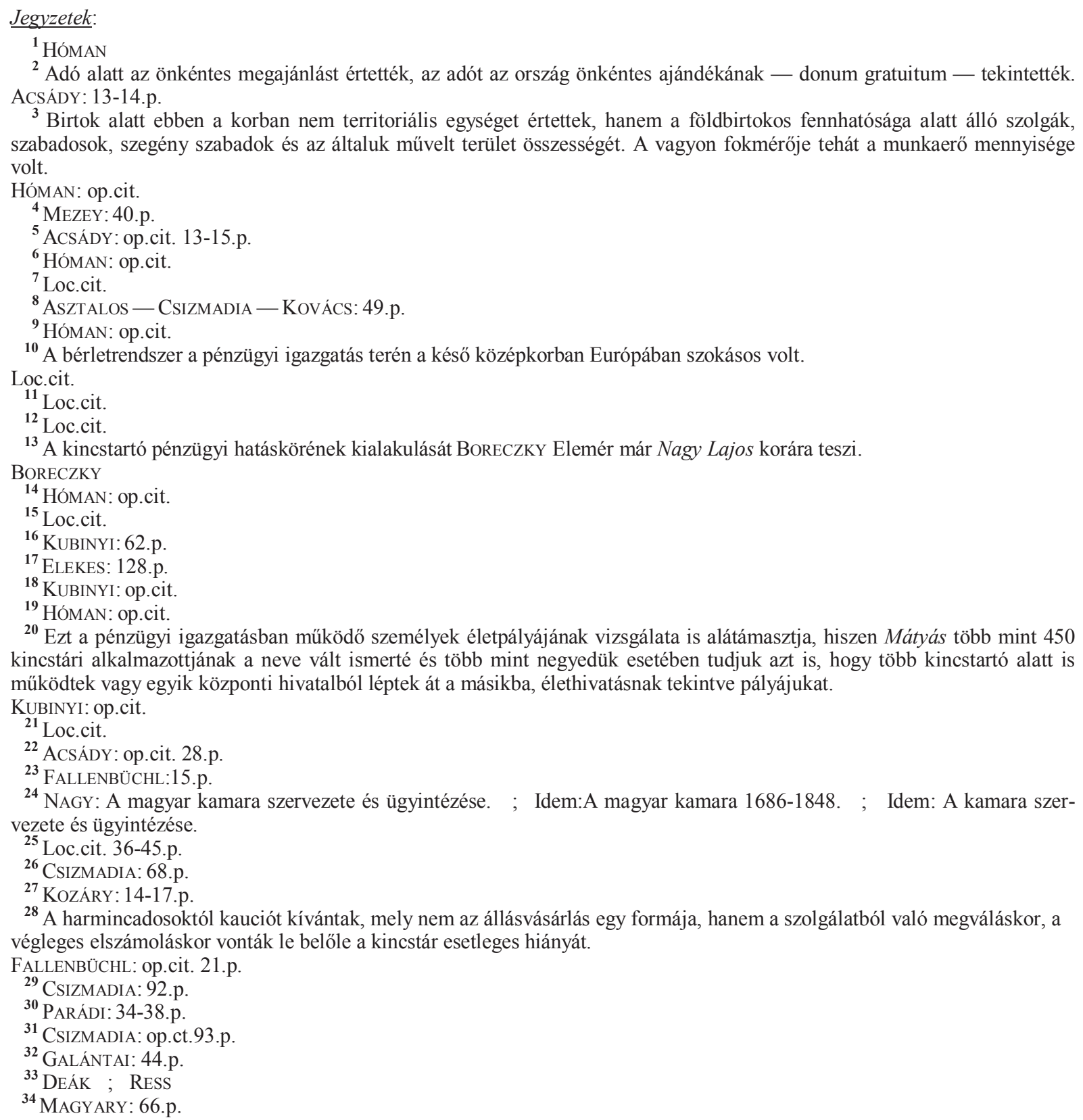


Jegyzetekben alkalmazott röviditések:

\section{MONOGRÁFIÁK, KISMONOGRÁFIÁK ÉS HASONLÓ JELLEGÜ KÖTETEK}

ACSÁDY

BORECZKY

CSIZMADIA

ELEKES

GALÁNTAI

HÓMAN

KOZÁRY

MAGYARY

MEZEY

NAGY: A magyar kamara szervezete és ügyintézése.

NAGY: A magyar kamara 1686-1848.

NAGY: A kamara szervezete és ügyintézése.

PARÁDI

\section{TANKÖNYVEK}

AsZTALOS - CSIZMADIA — KovÁCS

\section{ADATTÁRAK}

FALLENBÜCHL

\section{TANULMÁNYOK}

DEÁK

KUBINYI

RESS
ACSÁDY Ignácz: Magyarország pénzügyei I. Ferdinánd uralkodása alatt (1526-64.). Budapest, 1888, Magyar Tudományos Akadémia Történelmi Bizottsága. $280 \mathrm{p}$.

- BORECZKY Elemér: A királyi tárnokmester hivatala 1405-ig. Budapest, 1905, Községi Nyomda. 120 p.

CSIZMADIA Andor: A magyar közigazgatás fejlödése a XVIII. századtól a tanácsrendszer létrejöttéig. Budapest, 1976, Akadémia Kiadó. 560 p. HUISBN 9630507137.

- Elekes Lajos: Mátyás és kora. Budapest, 1956, Müvelt Nép Könyvkiadó. 188 p. /Magyar Történelmi Társulat, 5./

- GalÁntai József: A Habsburg-monarchia alkonya. Osztrák-magyar dualizmus 1867-1918. Budapest, 1985, Kossuth. 387 p. HU-ISBN 9630925893.

- Hóman Bálint: A Magyar Királyság pénzügyei és gazdaságpolitikája Károly Róbert korában. Budapest, 2003, Nap Kiadó. 326 p. HU-ISBN 963 940243 5. (Az 1921-ben publikált mü hasonmás kiadása.)

- KozÁRY Mónika: A nyugdijjrendszer Magyarországon Mária Teréziától a II. Világháborúig. Budapest, 2012, Gondolat. 366 p. HU-ISBN 97896369 3459 0. /Társadalombiztosítási könyvtár./ HU-ISSN 2063-2479.

- Magyary Zoltán: Magyar közigazgatás. A magyar közigazgatás szerepe a XX. század államában. A magyar közigazgatás szervezete, müködése és jogi rendje. Budapest, 1998, Polgári Tanácsadó Szolgálat. 675 p. HU-ISBN 963 760293 3. (1942-ben publikált mü hasonmás kiadása.)

- Mezey Barna (szerk.): Magyar alkotmánytörténet. Budapest, 2003, Osiris Kiadó. 516 p. 9789633895320.

— NAGY István: A magyar kamara szervezete és ügyintézése. 18-23.p. In FÁBIÁn Kiss Erzsébet et al. (szerk.): A Magyar Kamara és egyéb kincstári szervek. Budapest, 1995, Magyar Országos Levéltár. 575 p. HU-ISBN 96363 1072 6. /Levéltári leltárak, 9./ HU-ISSN 0209-5955.

- NAgY István: A magyar kamara 1686-1848. 24-33.p. In FÁBIÁN KISS Erzsébet et al. (szerk.): A Magyar Kamara és egyéb kincstári szervek. Budapest, 1995, Magyar Országos Levéltár. 575 p. HU-ISBN 9636310726. /Levéltári leltárak, 9./ HU-ISSN 0209-5955.

NAGY István: A kamara szervezete és ügyintézése. 34-60.p. In FÁBIÁN KISS Erzsébet et al. (szerk.): A Magyar Kamara és egyéb kincstári szervek. Budapest, 1995, Magyar Országos Levéltár. 575 p. HU-ISBN 9636310726. /Levéltári leltárak, 9./ HU-ISSN 0209-5955.

- PARÁDI József: A dualista Magyarország pénzügyi szerveinek határörizete 1867-1914. Budapest, 1987, Határörség. 123 p.

- AszTalos László — Csizmadia Andor — KovÁcs Kálmán: Magyar államés jogtörténet. Budapest, 2003, Nemzedékek Tudása Tankönyvkiadó. 574 p. HU-ISBN 9789631945669.

FALLENBÜCHL Zoltán (szerk.): Állami (királyi és császári) tisztségviselők a 17. századi Magyarországon. Budapest, 2002, Országos Széchényi Könyvtár - Osiris Kiadó. 377 p. HU-ISBN 963200458 2. /Nemzeti téka./ HU-ISSN 1586-1163.

- DEÁK Ágnes: Államrendőrségi információs hálózat Magyarországon 1849-1867. 84-89.p. In CSÓKA Ferenc: Szakszolgálat Magyarországon, avagy tanulmányok a hírszerzés és titkos adatgyüjtés világából 1785-2011. Budapest, 2012, Nemzetbiztonsági Szakszolgálat. 497 p. HU-ISBN 9789630832113.

- KuBINYI András: A kincstári személyzet a XV. század második felében. 62-79.p. In BARTA Gábor (szerk.): Mátyás király 1458-1490. Budapest, 1990, Akadémai Kiadó. 226 p. HU-ISBN 9630557940.

RESS Imre: A kormányzati hírszolgálat átalakulása az Osztrák-Magyar Monarchiában a kiegyezés után 1867-1875. 93-124.p. In CsÓKA Ferenc: Szakszolgálat Magyarországon, avagy tanulmányok a hírszerzés és titkos adatgyüjtés világából 1785-2011. Budapest, 2012, Nemzetbiztonsági Szakszolgálat. 497 p. HU-ISBN 9789630832113. 
A Magyar Királyság Pénzügyigazgatóságai a dualizmus időszakában
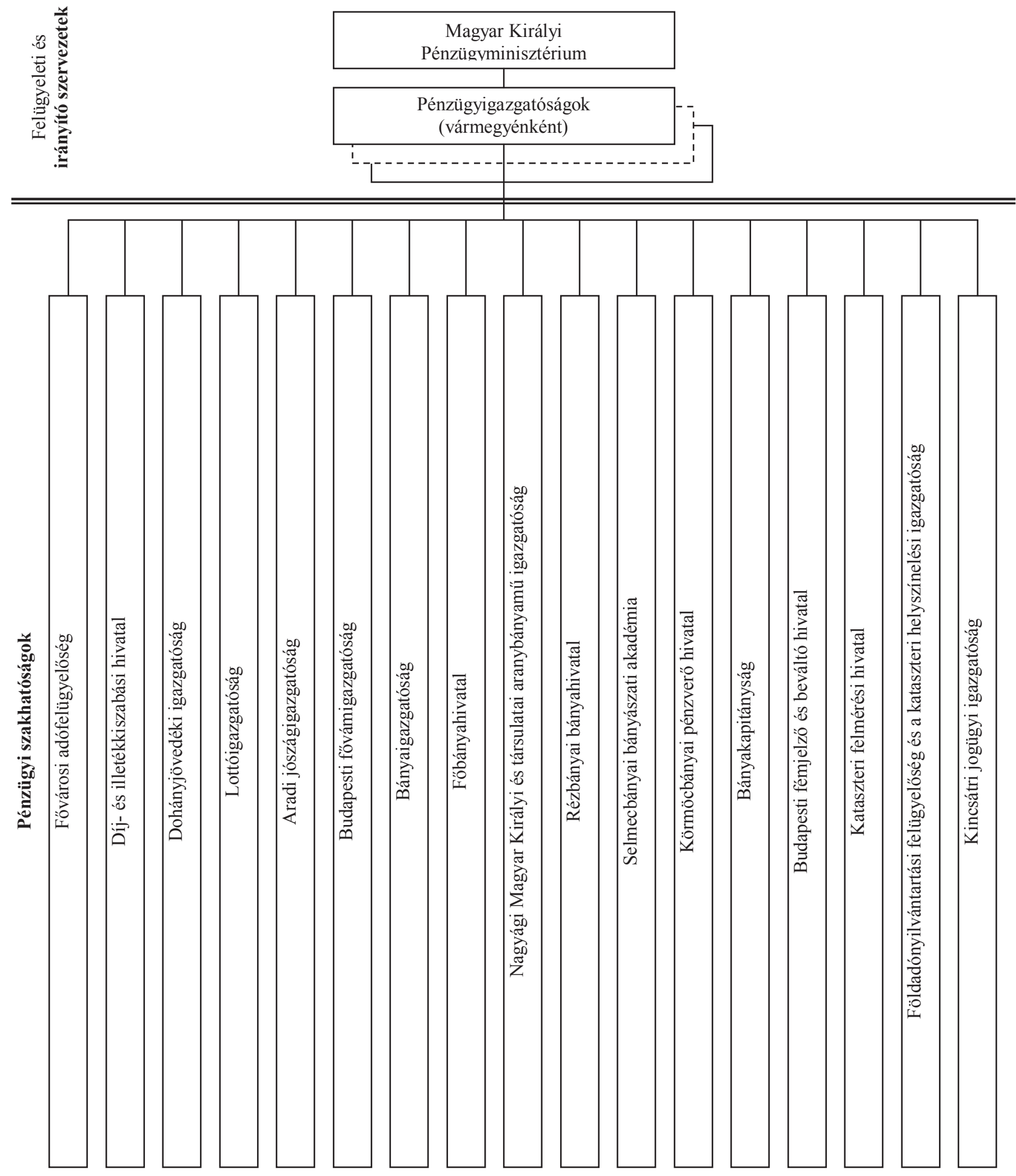

Megjegyzés: Nem müködött minden vármegyei pénzügyigazgatóságon valamennyi pénzügyi szakhatóság.

Forrás ! PARÁDI József: A dualista Magyarország pénzügyi szerveinek határőrizet 1867-1914. Budapest, 1987, Határőrség. 123 p. XII.sz. melléklet + VIII.sz.melléklet. 